American Journal of Immunology 6 (2): 20-24, 2010

ISSN 1553-619X

(C) 2010 Science Publications

\title{
Transforming Growth Factor- $\beta$ : An Indirect Inducer of Th17 Cell Differentiation both in Human and Murine System
}

\author{
J. Schumann \\ Institute of Physiological Chemistry, Faculty of Veterinary Medicine, \\ University of Leipzig, An den Tierkliniken 1, 04103 Leipzig, Germany
}

\begin{abstract}
Since their first description only some years ago Th17 cells have become of vital importance in immunological research. However, the role of TGF- $\beta$ in Th17 cell development is still a matter of controversial discussion. Predicted to have a key function in Th17 cell differentiation in the mouse TGF- $\beta$ was shown to inhibit IL-17 production of human $\mathrm{CD}^{+}{ }^{+} \mathrm{T}$ cells. Moreover, recent data indicate TGF- $\beta$ signaling in $\mathrm{T}$ cells to be dispensable for Th17 cell differentiation in the murine system. Hence, rather being a specie-specific factor TGF- $\beta$ is likely to act as an indirect inducer of Th17 cell differentiation both in mice and men.
\end{abstract}

Key words: Transforming growth factor, T helper cell, mice and men, murine system

\section{INTRODUCTION}

Th17 cells are a subset of $\mathrm{T}$ helper cell lymphocytes producing IL-17, TNF- $\alpha$ and IL-6, but not IFN- $\gamma$ or IL-4 (McKenzie et al., 2006; Iwakura and Ishigame, 2006). Via secretion of IL-17 Th17 cells enhance the expression of G-CSF (Fossiez et al., 1996; Cai et al., 1998; Schwarzenberger et al., 1998; 2001), IL-8 (Fossiez et al., 1996; Laan et al., 1999; Yao et al., 1995a; Kawaguchi et al., 2001; Katz et al., 2001; Jones and Chan, 2002; Prause et al., 2003) and ICAM-1 (Yao et al., 1995a; Albanesi et al., 1999) thereby promoting chemotaxis of neutrophils and monocytes to sites of inflammation. In addition, IL-17 stimulates the production of IL-6 (Fossiez et al., 1996; Yao et al., 1995a; 1995b; Katz et al., 2001; Chabaud et al., 1998), matrix metalloproteinases (Chabaud et al., 2000), prostaglandin E2 (Fossiez et al., 1996), NO (ShalomBarak et al., 1998; Attur et al., 1997) as well as the complement components C3 and factor B (Katz et al., 2000). Hence, Th17 cells represent potent proinflammatory mediators crucial in the regulation of inflammatory responses.

In a number of inquiries using murine models of host defense Th17 cells have been described to be important in the pathogenesis of chronic inflammatory diseases including arthritis (Lubberts et al., 2005; Latham et al., 2005), colitis (Zhang et al., 2006; Ogawa et al., 2004), encephalitis (Komiyama et al., 2006; Hofstetter et al., 2005) as well as asthma and allergy (Hellings et al., 2003). In humans IL-17 producing $\mathrm{T}$ cells have been isolated from synovial membranes and synovial fluid of patients suffering from rheumatoid arthritis (Chabaud et al., 1999). At this, severity of inflammation is reported to be consistent to the IL-17 concentration detectable in serum and tissue of the arthritis patients. Furthermore, a correlation between IL-17 serum levels and the degree of inflammatory processes has been described in the context of autoimmune encephalomyelitis (Lock and Heller, 2003) and inflammatory bowel disease (Fujino et al., 2003). Thus, IL-17 especially if produced by $\mathrm{T}$ cells is a likely candidate for intervention in chronic inflammatory diseases in men.

Th17 cell differentiation: Proceeding specie-specific? In the murine system the synergistic action of TGF- $\beta$ and IL- 6 has been considered to be essential for Th17 cell development, so far (Veldhoen et al., 2006; Mangan et al., 2006; Bettelli et al., 2006). In contrast, differentiation of human naïve $\mathrm{T}$ helper cells into Th17 cells has been reported not to depend on TGF- $\beta$ (Chen et al., 2007; Wilson et al., 2007; AcostaRodriguez et al., 2007; Manel et al., 2008; Santarlasci et al., 2009; Cosmi et al., 2008). Moreover, TGF- $\beta$ has been predicted to act suppressive on IL-17 production of human $\mathrm{CD}^{+} \mathrm{T}$ cells (Acosta-Rodriguez et al., 2007; Manel et al., 2008). Due to the divergent observations made in murine and human systems Th17 cells development in mice and men has been assumed to be regulated differentially (Annunziato et al., 2009; Annunziato and Romagnani, 2009). However, recent data provide evidence that TGF- $\beta$ is not directly required for the molecular orchestration of Th17 cell differentiation in 
the mouse as well (Das et al., 2009; Schumann, 2008). Thus, the situation seen in the murine system is closer related to the human situation as previously thought.

What role for TGF- $\beta$ in Th17 differentiation? TGF$\beta$ initially has been published as a growth factor (De Larco and Todaro, 1978). Thereinafter it was found, that TGF- $\beta$ not only influences differentiation of cells but is also crucial in inflammatory processes (Kehrl et al., $1986 a ; 1986 b)$. TGF- $\beta$ regulates the innate and the adaptive immunity affecting macrophages (Ashcroft, 1999), dendritic cells (Strobl and Knapp, 1999), T cells (Cerwenka and Swain, 1999), B cells (Lebman and Edmiston, 1999) and NK cells (Horwitz et al., 1999). The cytokine acts both pro- and antiinflammatory depending on genetic background, cell type, state of differentiation, extracellular matrix as well as the presence of other regulatory factors (McCartneyFrancis and Wahl, 1994; Wahl, 1994). Hence, TGF- $\beta$ shows a distinctive pleiotropy playing a complex role in immunmodulation.

At present time the role of TGF- $\beta$ in T helper cell differentiation has become of special interest. Depending on cytokine milieu naïve $\mathrm{T}$ helper cells differentiate into four known $\mathrm{T}$ helper cell subsets. TGF- $\beta$ interacts in this process by several ways. Both Th1 (Gorelik et al., 2002; Lin et al., 2005) and Th2 cells (Chen et al., 2003a; Gorelik et al., 2000; Heath et al., 2000) are inhibited by TGF- $\beta$. Concomitantly, TGF- $\beta$ represents the direct inducer of Treg cells, which themselves are considerable producers of the cytokine (Chen et al., 2003b).

Beside its clear role in Treg cell development conflicting data have been published concerning the relevance of TGF- $\beta$ in Th17 cell generation in mice and men. In murine system cytokines critically for Th17 cell differentiation were propagated to be TGF- $\beta$ and IL-6 (Veldhoen et al., 2006; Mangan et al., 2006; Bettelli et al., 2006). However, TGF- $\beta$ has not been shown to directly promote the generation of IL-17 producing $\mathrm{T}$ cells from naïve precursors. Rather, a beneficial effect of TGF- $\beta$ was seen, when naive CD4 ${ }^{+}$ $\mathrm{T}$ cells were co-cultivated with Treg cells plus dendritic cells and stimulated with anti-CD3-antibody as well as Lipopolysaccharid (LPS) (Veldhoen et al., 2006). LPS is known as strong inducer of Th1 reactions via a release of IL-12 by dendritic cells (Pearce et al., 2006). The effect of TGF- $\beta$ in such a setting might therefore rather be based on the prevention of a Th1 cell development. Consistently to this assumption, using a mouse model unable to generate Th1 and Th2 cells, the cytokine IL- 6 has been reported to be sufficient to drive
Th17 cell generation (Das et al., 2009). In addition, TGF- $\beta$ was shown not to affect the expression of the retinoic acid receptor-Related Orphan Receptor $\gamma \mathrm{t}$ (ROR $\gamma \mathrm{t}$ ), a Th17 cell specific transcription factor (Das et al., 2009). Beyond that, Th17 cells could be detected in a transgene mouse strain $\mathrm{T}$ cell specific insensitive for TGF- $\beta$ signaling (Schumann, 2008). Visualization of Th17 cells succeeded both ex vivo after re-stimulation of lymph node cells of B. burgdorferiinfected mice as well as in vitro after $\mathrm{T}$ cell specific stimulation of splenocytes and purified $\mathrm{CD}^{+}$ lymphocytes (Schumann, 2008). In contrast, stimulation of T cells over-expressing TGF- $\beta$ resulted in decreased Th17 cell numbers in comparison to the wild type (Schumann, 2008). Hence, there is compelling evidence that TGF- $\beta$ does not act as a direct inducer of Th17 cell development in the mouse.

The dispensability of TGF- $\beta$ signaling on T cells for Th17 cell development in the murine system is consistent to publications dealing with effects of TGF- $\beta$ on human $\mathrm{T}$ helper cell differentiation. In human system TGF- $\beta$ has been shown to inhibit IL-17 production by $\mathrm{T}$ cells (Acosta-Rodriguez et al., 2007; Manel et al., 2008). According hitherto existing literature rather than TGF- $\beta$, cytokines such as IL-1 $\beta$ and IL-23 drive Th17 cell development from human $\mathrm{CD}^{+}$precursors (Chen et al., 2007; Wilson et al., 2007; Acosta-Rodriguez et al., 2007).

TGF- $\beta$ affects Th17 cell differentiation in an indirect way: TGF- $\beta$ is part of a complex regulatory system critically in immune homeostasis. The cytokine is of vital importance in $\mathrm{T}$ helper cell differentiation influencing all four known $\mathrm{T}$ helper cell subsets. In addition to interference in $\mathrm{T}$ helper cell development TGF- $\beta$ represents the main product of Treg cells thereby mediating the immunosuppressive and anti-inflammatory function of these cells (Chen et al., 2003b).

Of note, the cytokine accomplishes its effects both directly and indirectly. TGF- $\beta$ directly induces Treg cell differentiation via promotion of the transcription factor FoxP3 (Chen et al., 2003b). TGF- $\beta$ directly blocks Th1 as well as Th2 cell development via inhibition of T-bet (Gorelik et al., 2002; Lin et al., 2005) and GATA-3 (Chen et al., 2003a; Gorelik et al., 2000; Heath et al., 2000) expression, respectively. By contrast, Th17 cell differentiation is affected indirectly by TGF- $\beta$. IFN- $\gamma$ and IL-4, the cytokines produced by Th1 and Th2 cells, are well known inhibitors of Th17 cell development. Hence, blocking of Th1 and Th2 cells linked with the absence of IFN- $\gamma$ and IL- 4 provides a milieu optimal for naïve $\mathrm{CD}^{+}$precursors to 
differentiate into Th17 cells (Veldhoen et al., 2006; Mangan et al., 2006; Bettelli et al., 2006; InfanteDuarte et al., 2000). Taken together, the impact of TGF- $\beta$ in $\mathrm{T}$ helper cell specification both in human and murine system is due to its inhibitory action on Th1 and Th2 cells in addition to its direct promotion of Treg cell amplification.

Conflict of interest: The author discloses any financial and personal relationships with other people or organizations that could inappropriately influence her work.

\section{REFERENCES}

Acosta-Rodriguez, E.V., G. Napolitani, A. Lanzavecchia and F. Sallusto, 2007. Interleukins 1beta and 6 but not transforming growth factor-beta are essential for the differentiation of interleukin 17-producing human T helper cells. Nat. Immunol., 8: 942-949. PMID: 17676045

Albanesi, C., A. Cavani and G. Girolomoni, 1999. IL17 is produced by nickel-specific $\mathrm{T}$ lymphocytes and regulates ICAM-1 expression and chemokine production in human keratinocytes: Synergistic or antagonist effects with IFN-gamma and TNFalpha. J. Immunol., 162: 494-502. PMID: 9886425

Annunziato, F. and S. Romagnani, 2009. Do studies in humans better depict Th17 cells? Blood, 114: 2213-2219. PMID: 19494349

Annunziato, F., L. Cosmi, F. Liotta, E. Maggi and S. Romagnani, 2009. Human Th17 cells: Are they different from murine Th17 cells? Eur. J. Immunol., 39: 637-640. PMID: 19283714

Ashcroft, G.S., 1999. Bidirectional regulation of macrophage function by TGF-beta. Microbes Infect., 1: 1275-1282. PMID: 10611755

Attur, M.G., R.N. Patel, S.B. Abramson and A.R. Amin, 1997. Interleukin-17 up-regulation of nitric oxide production in human osteoarthritis cartilage. Arthritis Rheum., 40: 1050-1053. DOI: 10.1002/art.1780400609

Bettelli, E., Y. Carrier, W. Gao, T. Korn and T.B. Strom et al., 2006. Reciprocal developmental pathways for the generation of pathogenic effector $\mathrm{T}_{\mathrm{H}} 17$ and regulatory $\mathrm{T}$ cells. Nature, 441: 235-238. DOI: $10.1038 /$ nature04753

Cai, X.Y., C.P. Gommoll, Jr., L. Justice, S.K. Narula and J.S. Fine, 1998. Regulation of granulocyte colony-stimulating factor gene expression by interleukin-17. Immunol. Lett., 62: 51-58. DOI: 10.1016/S0165-2478(98)00027-3
McCartney-Francis, N.L. and S.M. Wahl, 1994. Transforming growth factor beta: A matter of life and death. J. Leukoc. Biol., 55: 401-409. PMID: 8120457

Cerwenka, A. and S.L. Swain, 1999. TGF- $\beta 1$ : Immunosuppressant and viability factor for $T$ lymphocytes. Microbes Infect., 1: 1291-1296. DOI: 10.1016/S1286-4579(99)00255-5

Chabaud, M., F. Fossiez, J.L. Taupin and P. Miossec, 1998. Enhancing effect of IL-17 on IL-1-induced IL-6 and leukemia inhibitory factor production by rheumatoid arthritis synoviocytes and its regulation by Th2 cytokines. J. Immunol., 161: 409-414. http://www.jimmunol.org/cgi/reprint/161/1/409.pdf

Chabaud, M., J.M. Durand, N. Buchs, F. Fossiez and G. Page et al., 1999. Human interleukin-17: A T cell-derived proinflammatory cytokine produced by the rheumatoid synovium. Arthritis Rheum., 42: $\quad 963-970$. DOI: $10.1002 / 1529-$ 0131(199905)42:5<963::AID-ANR15>3.0.CO;2-E

Chabaud, M., P. Garnero, J.M. Dayer, P.A. Guerne and F. Fossiez et al., 2000. Contribution of interleukin 17 to synovium matrix destruction in rheumatoid arthritis. Cytokine, 12: 1092-1099. DOI: 10.1006/cyto.2000.0681

Chen, C.H., C. Seguin-Devaux, N.A. Burke, T.B. Oriss and S.C. Watkins et al., 2003a. Transforming growth factor $\beta$ blocks Tec kinase phosphorylation, $\mathrm{Ca}^{2+}$ influx and NFATc translocation causing inhibition of $\mathrm{T}$ cell differentiation. J. Exp. Med., 197: 1689-1699. DOI: 10.1084/jem.20021170

Chen, W.J., W.W. Jin, N. Hardegen, K.J. Lei and L. Li et al., 2003b. Conversion of peripheral $\mathrm{CD} 4^{+} \mathrm{CD} 25^{-}$ Naive $\mathrm{T}$ Cells to $\mathrm{CD} 4^{+} \mathrm{CD} 25^{+}$regulatory $\mathrm{T}$ cells by TGF- $\beta$ induction of transcription factor Foxp3. J. Exp. Med., 198: 1875-1886.

Chen, Z., C.M. Tato, L. Muul, A. Laurence and J.J. O'Shea, 2007. Distinct regulation of interleukin-17 in human T helper lymphocytes. Arthritis Rheum., 56: 2936-2946. DOI: 10.1002/art.22866

Cosmi, L., R.D. Palma, V. Santarlasci, L. Maggi and M. Capone et al., 2008. Human interleukin 17producing cells originate from a CD $161^{+} \mathrm{CD} 4^{+} \mathrm{T}$ cell precursor. J. Exp. Med., 205: 1903-1916. http://jem.rupress.org/content/205/8/1903.full.pdf

Das, J., G. Ren, L. Zhang, A.I. Roberts and X. Zhao et al., 2009. Transforming growth factor beta is dispensable for the molecular orchestration of Th17 cell differentiation. J. Exp. Med., 206: 2407-2416. DOI: $10.1084 /$ jem.20082286120409c

De Larco, J.E. and G.J. Todaro, 1978. Growth factors from murine sarcoma virus-transformed cells. Proc. Natl. Acad. Sci. USA., 75: 4001-4005. http://www.pnas.org/content/75/8/4001.full.pdf 
Fossiez, F., O. Djossou, P. Chomarat, L. Flores-Romo and S. It-Yahia et al., 1996. T cell interleukin-17 induces stromal cells to produce proinflammatory and hematopoietic cytokines. J. Exp. Med., 183: 2593-2603. DOI: 10.1084/jem.183.6.2593

Fujino, S., A. Andoh, S. Bamba, A. Ogawa and K. Hata et al., 2003. Increased expression of interleukin 17 in inflammatory bowel disease. Gut, 52: 65-70. DOI: 10.1136/gut.52.1.65

Gorelik, L., P.E. Fields and R.A. Flavell, 2000. Cutting edge: TGF-beta inhibits Th type 2 development through inhibition of GATA-3 expression. J. Immunol., $\quad$ 165: 4773-4777. http://www.jimmunol.org/cgi/reprint/165/9/4773.pdf

Gorelik, L., S. Constant and R.A. Flavell, 2002. Mechanism of transforming growth factor $\beta$ induced inhibition of $\mathrm{T}$ helper type 1 differentiation. J. Exp. Med., 195: 1499-1505. DOI: $10.1084 /$ jem.20012076

Heath, V.L., E.E. Murphy, C. Crain, M.G. Tomlinson and A. O'Garra, 2000. TGF- $\beta 1$ down-regulates Th2 development and results in decreased IL-4induced STAT6 activation and GATA-3 expression. Eur. J. Immunol., 30: 2639-2649. DOI: 10.1002/1521-4141(200009)30:9<2639::AIDIMMU2639>3.0.CO;2-7

Hellings, P.W., A. Kasran, Z. Liu, P. Vandekerckhove and A. Wuyts et al., 2003. Interleukin-17 orchestrates the granulocyte influx into airways after allergen inhalation in a mouse model of allergic asthma. Am. J. Respir. Cell Mol. Biol., 28: 42-50. DOI: $10.1165 / \mathrm{rcmb} .4832$

Hofstetter, H.H., S.M. Ibrahim, D. Koczan, N. Kruse and A. Weishaupt et al., 2005. Therapeutic efficacy of IL-17 neutralization in murine experimental autoimmune encephalomyelitis. Cell Immunol., 237: 123-130. PMID: 16386239

Horwitz, D.A., J.D. Gray and K. Ohtsuka, 1999. Role of NK cells and TGF- $\beta$ in the regulation of T-celldependent antibody production in health and autoimmune disease. Microbes Infect., 1: 1305-1311. DOI: 10.1016/S1286-4579(99)00253-1

Infante-Duarte, C., H.F. Horton, M.C. Byrne and T. Kamradt, 2000. Microbial lipopeptides induce the production of IL-17 in Th cells. J. Immunol., 165: 6107-6115. PMID: 11086043

Iwakura, Y. and H. Ishigame, 2006. The IL-23/IL-17 axis in inflammation. J. Clin. Invest., 116: 1218-1222. DOI: $10.1172 / \mathrm{JCI} 28508$

Jones, C.E. and K. Chan, 2002. Interleukin-17 stimulates the expression of interleukin-8, growthrelated oncogene-alpha and granulocyte-colonystimulating factor by human airway epithelial cells. Am. J. Respir. Cell Mol. Biol., 26: 748-753. http://ajrcmb.atsjournals.org/cgi/content/full/26/6/748
Katz, Y., O. Nadiv and Y. Beer, 2001. Interleukin-17 enhances tumor necrosis factor $\alpha$-induced synthesis of interleukins 1, 6 and 8 in skin and synovial fibroblasts: A possible role as a "fine-tuning cytokine" in inflammation processes. Arthritis Rheum., 44: 2176-2184. DOI: 10.1002/15290131(200109)44:9<2176::AID-ART371>3.0.CO;2-4

Katz, Y., O. Nadiv, M.J. Rapoport and M. Loos, 2000. IL-17 regulates gene expression and protein synthesis of the complement system, C3 and factor $\mathrm{B}$, in skin fibroblasts. Clin. Exp. Immunol., 120: 22-29. DOI: $10.1046 /$ j.13652249.2000.01199.x

Kawaguchi, M., F. Kokubu, H. Kuga, S. Matsukura and H. Hoshino et al., 2001. Modulation of bronchial epithelial cells by IL-17. J. Allergy Clin. Immunol., 108: 804-809. DOI: 10.1067/mai.2001.119027

Kehrl, J.H., A.B. Roberts, L.M. Wakefield, S. Jakowlew and M.B. Sporn et al., 1986a. Transforming growth factor beta is an important immunomodulatory protein for human B lymphocytes. J. Immunol., 137: 3855-3860. PMID: 2878044

Kehrl, J.H., L.M. Wakefield, A.B. Roberts, S. Jakowlew and M. Varez-Mon et al., 1986b. Production of transforming growth factor beta by human $\mathrm{T}$ lymphocytes and its potential role in the regulation of $\mathrm{T}$ cell growth. J. Exp. Med., 163: 1037-1050. PMID: 2871125

Komiyama, Y., S. Nakae, T. Matsuki, A. Nambu and H. Ishigame et al., 2006. IL-17 plays an important role in the development of experimental autoimmune encephalomyelitis. J. Immunol., 177: 566-573. PMID: 16785554

Laan, M., Z.H. Cui, H. Hoshino, J. Lotvall and M. Sjostrand et al., 1999. Neutrophil recruitment by human IL-17 via C-X-C chemokine release in the airways. J. Immunol., 162: 2347-2352. PMID: 9973514

Latham, K.A., K.B. Whittington, R. Zhou, Z. Qian and E.F. Rosloniec, 2005. Ex vivo characterization of the autoimmune $\mathrm{T}$ cell response in the HLA-DR1 mouse model of collagen-induced arthritis reveals long-term activation of type II collagen-specific cells and their presence in arthritic joints. J. Immunol., 174: 3978-3985. PMID: 15778354

Lebman, D.A. and J.S. Edmiston, 1999. The role of TGF-beta in growth, differentiation and maturation of B lymphocytes. Microbes Infect., 1: 1297-1304. PMID: 10611758

Lin, J.T., S.L. Martin, L. Xia and J.D. Gorham, 2005. TGF-beta 1 uses distinct mechanisms to inhibit IFN-gamma expression in $\mathrm{CD}^{+} \mathrm{T}$ cells at priming and at recall: Differential involvement of Stat 4 and T-bet. J. Immunol., 174: 5950-5958. PMID: 15879087 
Lock, C.B. and R.A. Heller, 2003. Gene microarray analysis of multiple sclerosis lesions. Trends Mol. Med., $\quad 9: \quad 535-541 . \quad$ DOI: 10.1016/j.molmed.2003.10.008

Lubberts, E., M.I. Koenders and W.B. van den Berg, 2005. The role of T-cell interleukin-17 in conducting destructive arthritis: Lessons from animal models. Arthritis Res. Ther., 7: 29-37. PMID: 15642151

Manel, N., D. Unutmaz and D.R. Littman, 2008. The differentiation of human $\mathrm{T}(\mathrm{H})-17$ cells requires transforming growth factor-beta and induction of the nuclear receptor RORgammat. Nat. Immunol., 9: 641-649. PMID: 18454151

Mangan, P.R., L.E. Harrington, D.B. O'Quinn, W.S. Helms and D.C. Bullard et al., 2006. Transforming growth factor-beta induces development of the $\mathrm{T}(\mathrm{H}) 17$ lineage. Nature, 441: 231-234. PMID: 16648837

McKenzie, B.S., R.A. Kastelein and D.J. Cua, 2006. Understanding the IL-23-IL-17 immune pathway. Trends. Immunol., 27: 17-23. PMID: 16290228

Ogawa, A., A. Andoh, Y. Araki, T. Bamba and Y. Fujiyama, 2004. Neutralization of interleukin-17 aggravates dextran sulfate sodium-induced colitis in mice. Clin. Immunol., 110: 55-62. PMID: 14962796

Pearce, E.J., C.M. Kane and J. Sun, 2006. Regulation of dendritic cell function by pathogen-derived molecules plays a key role in dictating the outcome of the adaptive immune response. Chem. Immunol. Allergy, 90: 82-90. PMID: 16210904

Prause, O., M. Laan, J. Lotvall and A. Linden, 2003. Pharmacological modulation of interleukin-17induced GCP-2-, GRO-alpha- and interleukin-8 release in human bronchial epithelial cells. Eur. J. Pharmacol., 462: 193-198. PMID: 12591113

Santarlasci, V., L. Maggi, M. Capone, F. Frosali and V. Querci et al., 2009. TGF-beta indirectly favors the development of human Th17 cells by inhibiting Th1 cells. Eur. J. Immunol., 39: 207-215. PMID: 19130583

Schumann, J., 2008 . Transformierender Wachstumsfaktor-beta (TGF- $\beta$ ) und GranulozytenMakrophagen Kolonie-Stimulierender Faktor (GMCSF) in der Pathogenese der Lyme-Borreliose und der Spezifizierung von T-Helferzell-Populationen.
Schwarzenberger, P., R. La, A. Miller, P. Ye and W. Huang et al., 1998. IL-17 stimulates granulopoiesis in mice: Use of an alternate, novel gene therapyderived method for in vivo evaluation of cytokines. J. Immunol., 161: 6383-6389. PMID: 9834129

Schwarzenberger, P., W. Huang, P. Oliver, P. Byrne and R. La et al., 2001. Il-17 mobilizes peripheral blood stem cells with short-and long-term repopulating ability in mice. J. Immunol., 167: 2081-2086. PMID: 11489991

Shalom-Barak, T., J. Quach and M. Lotz, 1998. Interleukin-17-induced gene expression in articular chondrocytes is associated with activation of mitogen-activated protein kinases and NF-kappaB. J. Biol. Chem., 273: 27467-27473. PMID: 9765276

Strobl, H. and W. Knapp, 1999. TGF-beta1 regulation of dendritic cells. Microbes Infect., 1: 1283-1290. PMID: 10611756

Veldhoen, M., R.J. Hocking, C.J. Atkins, R.M. Locksley and B. Stockinger, 2006. TGFbeta in the context of an inflammatory cytokine milieu supports de novo differentiation of IL-17producing T cells. Immunity, 24: 179-189. PMID: 16473830

Wahl, S.M., 1994. Transforming growth factor beta: the good, the bad and the ugly. J. Exp. Med., 180: 1587-1590. PMID: 7964446

Wilson, N.J., K. Boniface, J.R. Chan, B.S. McKenzie and W.M. Blumenschein et al., 2007. Development, cytokine profile and function of human interleukin 17-producing helper $\mathrm{T}$ cells. Nat. Immunol., 8: 950-957. PMID: 17676044

Yao, Z., S.L. Painter, W.C. Fanslow, D. Ulrich and B.M. Macduff et al., 1995a. Human IL-17: A novel cytokine derived from $\mathrm{T}$ cells. J. Immunol., 155: 5483-5486. PMID: 7499828

Yao, Z., W.C. Fanslow, M.F. Seldin, A.M. Rousseau and S.L. Painter et al., 1995b. Herpesvirus Saimiri encodes a new cytokine, IL-17, which binds to a novel cytokine receptor. Immunity, 3: 811-821. PMID: 8777726

Zhang, Z., M. Zheng, J. Bindas, P. Schwarzenberger and J.K. Kolls, 2006. Critical role of IL-17 receptor signaling in acute TNBS-induced colitis. Inflamm. Bowel. Dis., 12: 382-388. PMID: 16670527 